\title{
Qualification paths of adult educators in Sweden and Denmark
}

\author{
Per Andersson, Susanne Köpsén, Anne Larson and Marcella Milana
}

\section{Linköping University Post Print}

N.B.: When citing this work, cite the original article.

This is an electronic version of an article published in:

Per Andersson, Susanne Köpsén, Anne Larson and Marcella Milana, Qualification paths of adult educators in Sweden and Denmark, 2012, Studies in Continuing Education. Studies in Continuing Education is available online at informaworld ${ }^{\mathrm{TM}}$ :

http://dx.doi.org/10.1080/0158037X.2012.712036

Copyright: Taylor \& Francis (Routledge)

http://www.routledge.com/

Postprint available at: Linköping University Electronic Press

http://urn.kb.se/resolve?urn=urn:nbn:se:liu:diva-80702 


\title{
Qualification paths of adult educators in Sweden and Denmark
}

\author{
Per Andersson ${ }^{\mathrm{a} *}$, Susanne Köpsén ${ }^{\mathrm{a}}$, Anne Larson $^{\mathrm{b}}$ and Marcella Milana ${ }^{\mathrm{b}}$ \\ ${ }^{a}$ Department of Behavioural Sciences and Learning, Linköping University, Linköping, Sweden \\ ${ }^{b}$ Danish School of Education, Aarhus University, Copenhagen, Denmark \\ *Corresponding author. Email: per.andersson@liu.se
}

\begin{abstract}
The qualification of adult educators is a central aspect of the quality of adult education. However, within current policy discourses and adult education research on the professional development of prospective adult educators, little attention is paid to teacher qualification when compared to other fields of education and training. In this study, we analyse the qualification paths, or learning trajectories, of prospective adult educators in Sweden and Denmark. The analysis is based on narrative interviews with 29 students in training to become adult educators. The career paths of adult educators are often long and winding roads. Becoming an adult educator could be their primary desire, but it could also be their 'Plan B', a second choice. Individual motives and external demands interact in the professionalisation process. A shift in focus from teaching subject and methods to teaching context and the relation to the learners is part of the professional development. Finally, we argue that both academic studies and hands-on work in the adult education community are crucial parts of the adult educator's qualification path.
\end{abstract}

\section{Keywords}

adult educator; professionalisation; qualification; learning trajectory

\section{Introduction}

In modern societies, lifelong learning is considered necessary to guarantee economic and social development, to reinforce democratic participation and to strengthen social cohesion. Consequently, national and international strategies for lifelong learning have embraced not only reforms of compulsory or basic education but also structural intervention in the field of adult education and training. These changes have created new demands for adult educators as a professional group, such as the need to plan, administer and manage programs and to teach, guide, counsel, support and evaluate learning outside the specific institutional contexts for adult education (EC 2006, 2007a, b; European Journal of Education 2009; Merriam and Brockett 2007; Nuissl and Lattke 2008).

Practitioners and researchers are concerned about the need to qualify current adult educators. This concern is exemplified by the flourishing numbers of national and cross-national studies that illuminate the influences of societal, educational and occupational contexts on adult 
educators' professional development (e.g., Buiskool et al. 2009; Jütte et al. 2011; Nuissl and Egetenmeyer 2010; Nuissl and Lattke 2008; Research-voor-Beleid/PLATO 2008). In Europe, the adult education field is characterised by fragmented training and, therefore, several pathways and individual decisions for professional development, with staff who often enter the field late in their professional lives. Flexibility in employment requires flexible training, and particularly in-service training, to support the professionalisation of adult educators (Buiskool, et al. 2009; Przybylska 2008; Research-voor-Beleid/PLATO 2008). This seems to be true also in Denmark and Sweden, the context of this study, but there is a higher degree of employment security for adult educators in these countries (Andersson 2007a, b).

Furthermore, whereas national policies emphasise the quality of adult education and training, neither current policy discourses nor adult education research pay adequate attention to the initial education, pre-service training and professional development of prospective adult educators when compared to other fields of education and training (including primary and secondary school, initial vocational education and training). This is the case even in countries such as Denmark and Sweden that have a long tradition of and extensive practice in adult education (Milana, Andersson, Farinelli et al. 2010; Milana, Andersson, Gross et al. 2010). The traditions of adult education in Denmark and Sweden are the basis for studying the qualification paths and professional development of adult educators in these two countries.

Like other education professionals, adult educators play a focal role in ensuring the quality of the teaching-learning processes that take place in varying educational settings. They are, however, unique because although adult educators have often acquired a specialisation in the course of their initial studies, they often lack formal preparation for teaching adults prior to entering the profession. Hence, questioning how prospective adult educators prepare themselves to perform according to high quality standards in a changing work environment is a constructive goal. This paper seeks to understand the qualifications paths and professional development of prospective adult educators in Sweden and Denmark through an analysis of their individual professional learning trajectories.

\section{The context of adult educators in Denmark and Sweden}

These trajectories have developed in the context of Danish and Swedish adult education. Both countries have a tradition of adult education dating to the mid-nineteenth century. Today they have a publicly funded 'system' of adult education that consists of general, vocationally oriented and liberal adult education. In recent years, the focus in Denmark has been on expanding the scope and coverage of adult and vocational training, which has led to an increased supply of education and training opportunities. In Sweden, adult education policy is presently directed toward strengthening vocational adult education. However, although adult education and training has gained much attention in policy discussions in Denmark, the qualifications of current and prospective teachers have only recently captured the attention of politicians. Primary considerations have been given to those working or willing to work in vocationally oriented adult education. Sweden has a strong policy emphasis on the qualifications or status of teachers in general, but little specificity with respect to adult educators. 
Few official requirements or specialised qualifications are necessary to teach adults. Nevertheless, Danes willing to acquire specialised competences in teaching adults can enrol in a variety of basic courses as well as diploma and masters programmes as part of their professional development. However, no specialised provisions exist in the mainstream education system that provide specialised knowledge about teaching adults. All programmes for adult educators are open to practitioners in both youth and adult education; accordingly, these programmes primarily address people already working within the field of adult education and training rather than prospective teachers of adults. In Sweden, formal education and training for becoming an adult educator is not very extensive. A targeted training programme at the university level is offered for adult educators in the field of liberal adult education. However, non-formal, liberal adult education has no formal requirements. Swedish universities quite frequently offer separate courses in adult education and learning, mainly available at a basic level, but these courses do not focus on developing teacher competence. Rather, they have a broader focus on adult learning in different contexts, such as the working life and/or more general aspects of adult learning. The teaching degree that is required in formal adult education is not a specialised qualification for teaching adults but rather a qualification for becoming a teacher in general.

Thus the situation in Sweden and Denmark has both similarities and differences. In their national policies, the rationale for adult educators is neither analysed nor discussed. As a consequence, the adult educator does not have a high status in either country, and more specifically, adult education competence is not adequately valued. The main difference is that Denmark has a broader spectrum of opportunities targeting prospective adult educators as part of its adult education and training system, whereas Sweden has one integrated higher education system that includes all the existing opportunities (Milana, Andersson, Farinelli et al. 2010; Milana, Andersson, Gross et al. 2010).

\section{The adult educator}

'Adult educator' is a broad category including people involved in the provision of adult education opportunities. However, our focus is on those who are or will be working as teachers/trainers in direct contact with adult learners. We use the terms 'educator' and 'teacher' interchangeably. Furthermore, our study addresses both active (but uncertified) and prospective adult educators who earn or intend to earn their living in the adult education field. The extensive and important voluntary work in adult education is beyond the scope of our study. Finally, we examine the professional development of adult educators for the fields of general, vocational and liberal adult education, i.e., those fields more or less regulated by the state, receiving public funding and bridging what has been described as a 'divide' between teachers and trainers (Santoro 2003). We discuss the 'prospective' adult educators who are preparing themselves to enter into the field of adult education, but in practice, there is no clear-cut distinction between prospective and active adult educators.

\section{Adult educator as a profession?}

The existing literature offers divergent views on professionalism (Cunningham 2008). It can be seen as the precondition for representing a competent and specialised practice, or it may concern the 
possession of the specific knowledge and skill controlled by occupational groups (Abbot 1988). Central criteria are often used to define professions such as 'teacher': a research-based professional education, a 'professional language', formal licensing or registration of the professional educator/teacher, ethical guidelines and a system of sanctions if these guidelines are not followed, and, finally, a certain degree of professional autonomy (e.g., Colnerud and Granström 2002). Following such criteria, the adult educator is not clearly a profession similar to the 'classical' professions (Jütte et al. 2011).

However, such definitions have been criticised as being too static and focused on attributes rather than activities. The on-going debate on 'new' professionalism includes investigations of the concepts and substances of professionalism (e.g., Evans 2008). Alternative models are processoriented, focus on professional development, and highlight aspects such as the acquisition of a specialised body of knowledge and the construction of a professional identity (see Milana, Andersson, Farinelli et al. 2010; Milana, Andersson, Gross et al. 2010, for extensive discussions on this matter). Such a process-oriented perspective is adopted in this study.

In adult education, educators are often professionals in different disciplines (the focus of their subject knowledge) when they begin their professional development as adult educators. This professional education, by contrast, has one unified aim: 'to make practitioners academics is the first step to create a profession' (Bron and Jarvis 2008, 42). However, professionalism encompasses not only (formal) competence but also the development of expertise in practice.

\section{Professional competence and qualification}

When we try to understand the professionalisation processes, we must understand that different aspects of professional knowledge define the profession and are required by authorities and employees. Of particular importance is the difference between formal and actual competence. A professional teacher should have the actual competence to be able to teach, but formal competence, i.e., the formal, research-based professional education and licensing of the members of the profession, is also central to defining a profession. This difference between formal and actual competence is reflected in the qualifications required in the labour market. Employers often, and in the case of a profession, must insist on formal requirements such as diplomas, degrees and licences. However, these qualifications do not necessarily reflect the competence needed to do a good job (Ellström 1992). Thus, although formal requirements are part of a profession's definition designed to secure a high level of competence among the professionals, a candidate who possesses concrete competence related to the actual demands of the job may be able to do the job in practice even if he or she lacks the formal competence. Nevertheless, if 'adult educator' were to become a profession, certain formal requirements would need to be fulfilled. This paper studies the individual learning trajectories viewed as paths to qualification, and, in analysing the results, considers different aspects of professional competence and required qualifications.

\section{Becoming an adult educator as part of socio-cultural activities}

Our theoretical framework for understanding the qualification paths of adult educators uses a socio- 
cultural approach that analyses learning in three levels of mutually defined and interdependent processes: the individual, interpersonal and system levels (Rogoff 1995). Our understanding is that individuals take part in activities in different social contexts, engaging with other people. Through this participation, they prepare themselves for later participation in adult education as a teacher. The system level corresponds to the cultural and institutional structures-including policies, educational programmes and courses - that provide the set of arrangements, resources and values appropriate for becoming an adult educator. The interpersonal level reflects the interpersonal engagements and arrangements involved throughout the process as an individual becomes an adult educator. Here, the interpersonal level is defined by the turning points, trigger events and impacts made by significant others. The individual level, namely qualification paths in this study, is understood here as a type of learning trajectory (Lave and Wenger 1991; Wenger 1998).

\section{Qualifications paths as learning trajectories in and between communities of practice}

We understand that learning and professionalisation processes for adult educators are situated in certain communities of practice (Lave and Wenger 1991). This perspective is applied to develop the understanding of how such processes are shaped in different communities-private and professional-when teaching in adult education and when participating in teacher education or courses targeting adult educators. Lave and Wenger (1991) use the concept of legitimate peripheral participation in analysing processes of learning within a community of practice. Learning is seen as a change in participation and follows a trajectory that could go from legitimate peripheral participation to central participation in the community of practice after the learner acquires the necessary knowledge and skills (Lave and Wenger 1991; Wenger 1998). Additionally, Wenger (1998) notes that the trajectory concept suggests not a foreseen or charted path, but rather a journey influenced by different fields and constantly moving through time in an arc connecting the past, present and future states of professionalisation. As individuals take part in different communities of practice (in private life and working life), their identities form trajectories both within and across communities. Our study considers that the qualification and professionalisation path to become an adult educator may be shaped by participating in multiple socio-cultural contexts.

The concepts of 'learning curriculum' and 'teaching curriculum' (Lave and Wenger 1991) are important in relation to learning trajectories in a community of practice. There is a difference between practical knowing, which may refer to a learning curriculum, and theoretical knowing, which may refer to a teaching curriculum. According to Lave and Wenger (1991), a teaching curriculum is constructed to instruct newcomers. By contrast, a learning curriculum is derived from everyday activity, such as participation in a community of practice, and is viewed from the learners' perspective. The differences between these curricula and the values they are given influence the type of qualification that is required for adult educators.

\section{Methods}

We believe that the individual motivations for working in the adult education field and the learning trajectories that lead to the acquisition of competences, qualifications and professional identities can be understood by applying a biographical perspective (Bertaux and Thompson 1997; Fischer- 
Rosenthal 2000). For example, Vähäsantanen and Eteläpelto (2009) investigate how teachers negotiate their professional identity by using a narrative method, and Maier-Gutheil and Hof (2011) use life histories in a longitudinal study on experienced adult educators' development of professionalism. Other researchers have also identified the need to know more about the background and life histories of adult educators (Buiskool et al. 2009; Research-voor-Beleid/PLATO 2008).

Narrative interviews provide important insights into people's learning experiences and the extent to which their specific learning arenas develop the viewpoints that guide their behaviour and shape their identities. Narratives convey information about an individual's participation in different learning contexts and the impact of such experiences on his or her life. On a related note, these processes of identity construction can enable the retrospective creation of coherence and meaning along the timeline of lived experience (Horsdal 2002). We see this perspective as consistent with our other socio-cultural theoretical framework and position ourselves within this biographical perspective.

The analysis draws on transcripts from 29 narrative interviews (14 Swedish and 15 Danish; 4 male and 25 female). Interviewees were currently or recently engaged in different types of training for adult educators, targeting the fields of general, vocational, or liberal adult education.

Each interview was collected in Danish or Swedish, and all interviews followed the same format. Once an interviewee had finished telling his/her life story, the researcher asked a number of pre-defined questions provided they had not spontaneously been answered by the interviewee (e.g., Can you talk about the path that you have taken in order to work in the field of adult learning? What made you choose this course, and how do you see yourself in a vocational/professional context?).

The analysis of interviews consisted of three main steps: (1) A single-case analysis was conducted. (2) A cross-case analysis in each country aimed at identifying similarities and variations on common themes within the sample was conducted. This analysis was based on parts of the interviews that were identified as relevant to the themes highlighted in the follow-up questions. The analysis included relevant information offered spontaneously in the initial narrative as well as answers to the follow-up questions. (3) Results from the national cross-case analyses were brought together in a common analysis focusing on the themes presented below.

\section{Trajectories of adult educators-to-be}

Our empirical results focus on how current and prospective adult educators choose the professional path of becoming an adult educator: what is their motivation for seeking formal qualification, and what understanding do they have of their professional role within current professional contexts? As one might expect, the career paths and professional development vary considerably.

\section{Paths to adult education}

A general pattern among the paths to adult education is that the prospective adult educators have not followed a 'straight way.' The pathways vary in regard to teacher background and significant 
turning points before entering the various courses or teacher education programmes. The interviewees were involved in different work activities and have diverse interests. However, some characteristics of their personal lives and histories were seen as significant in shaping their professional trajectories. The routes to their present positions are often long and winding. Different personal situations frame their actual trajectories, and their family and personal histories have influenced their choices along the road to professionalisation. A number of interviewees participated in adult education themselves, and some have experience as leaders or educators in formal as well as informal learning activities. Thus, adult education was rarely new for them. Following a parallel work/studies path was not unusual, i.e., working and studying at the same time, whereas family and home acted as frames for which choices were made possible. For example, having teachers in the family was interpreted by some interviewees as a sign of one's destiny to become a teacher/educator. Having a foreign background could also be described as influential; such subjects felt like they had to prove themselves in their new environment, with higher education and entering a profession being one way of showing this. Despite the differences in personal situations and histories, two main types of somewhat overlapping learning trajectories were identified.

Pursuing one's desire for a (new) career is significant for the first type of trajectory identified. This trajectory is typified by a person who has been working in an area other than education before entering teacher education and whose career reached a turning point following the choice to pursue this education. This turning point represented the start of a new career as an educator. Becoming a vocational teacher is an example of a new career, but it can also be seen as a 'career' within a vocation. As mentioned previously, a path of parallel work and study was not unusual:

During the period when I was working as a forklift driver, I was trained and certified as a forklift instructor. So the result was that I was working in parallel to my job as a forklift driver, while training forklift drivers. (Kristina, S [Swedish])

In this first type of trajectory, one can also find individuals who have chosen a career in education because of their interest and affection for a specific subject:

It started at university with Swedish as a separate course. This was close to my heart. Swedish was absolutely the best subject. At the same time, I was considering, what shall I do with this later on? Well, teacher, that would be fun. (Maria, S)

People who had already been working as uncertified teachers/educators followed a somewhat different trajectory within the first main type. Some of them had experience in adult education, and some from other types of educational work. For those working as uncertified teachers or educators, they identified their important turning point when they started to teach rather than when they entered their present course. In our sample, some people had been working for a long time as uncertified teachers, and others started teaching more recently. Actually, most interviewees had prior experience from various types of educational and pedagogical work. For example, in the Danish sample, we observed that nurses progressing in their career were asked to supervise nursing 
students during their hospital internships.

In this 'desire for a new career' category, the professional trajectories were shaped by personal situations. Interviewees started working as uncertified educators for many reasons. Personal situations influenced the actual opportunities available to them. On the other hand, some respondents described entering adult education as an uncertified educator as a coincidence.

Becoming an educator or teacher as a 'plan $B^{\prime}$ was the second main type of trajectory, one characterised by being a second choice. We have identified two varieties of 'plan B'. One variety is related to personal trigger events, such as illnesses, accidents or legal impediments, which made it difficult to stay in the former vocation.

I started to study to become a teacher because of an emerging allergy. I wanted to use the knowledge I have as a keeper of animals, and I think it is fun to be with pupils.

(Pernilla, S)

The other variety of 'plan B' was related to the education and labour market structures. If jobs in the subject area one has studied are not available, then becoming a teacher/educator in that same area is a convenient alternative; e.g., a biologist can become a biology teacher. In some cases, adult education was also a 'plan B' within the educational field; for example, some prospective upper secondary school teachers chose to become adult educators when a career in upper secondary school was not possible.

\section{Choice of current studies}

Here, we focus those turning points that were significant in the choice of a course or a programme for prospective adult educators. We found that individual motives and external demands were two types of interacting and often intertwined incentives related to the turning point.

The individual motives are of different kinds. Several interviewees described enrolling in further studies as a free choice, in which individual motives were central. For those who already had experience in educational work, particularly those working as 'acting teachers', the course could be seen as useful at work, e.g., as a way to 'get "tools"' to help them pursue their interest in teaching. Positive experiences as a pupil in school, including in adult education, have also influenced the choice, as have experiences from supervising in the workplace.

In other cases, the choice of adult education was based on a certain commitment to change one's life. One interviewee told how an adult educator had helped her to make an important turn in her life. By becoming an adult teacher, she expressed her desire to give the same kind of support to other adult learners herself:

My picture was that adult students would be very fun, as I had that experience myself. It is very much based upon my own positive experiences from that period. Exactly bringing something to life in the person! (Maria, S) 
Another main motive stated by some interviewees was the desire for formal recognition of the pedagogical knowledge they had gained through several years of working with adults: 'Now, I would like to have a recognised proof for what I can do within the pedagogical area' (Ellen, D [Danish]). Sometimes, the interviewees' lack of academic titles upon starting a job was seen as a barrier. As another interviewee puts it, without an academic title, 'many doors were closed to me' (Dorthe, D).

In this respect, the external demands are also central. An external motivator could influence those already acting as teachers in adult education. A teacher degree is normally necessary to getting a permanent job as a teacher in Sweden. However, it should be noted that this degree is not specialised in adult education.

A number of our interviewees (especially Danish) were invited by the employer to acquire further competences as adult educators during a 'workers development interview'. Broader structural conditions, such as on-going reforms of the education and government training system for social and health service workers and in police training schools, played an important role in this respect because formal qualifications relevant for teaching adults became an official requirement at the interviewees' workplaces.

Even so, the individual motives for following an employer's request for certification differ. A closer look at individual biographies sheds light on the complex dynamics that brought our interviewees to seek formal recognition in the field of adult education at a given time in their lives at the employer's request. This request could create a kind of synchronisation between social forces and personal needs for an educator who had always struggled for better recognition and acceptance at work. Acquiring formal qualifications that are relevant for teaching adults was in some cases seen as useful in case, at a later stage in life, that teacher decides to pursue his or her originally intended career as an upper secondary school teacher. A number of interviewees found the study path suggested by the employer highly relevant to their jobs; however, the formal qualification could also be thought of as a step towards further studies, not least to improve one's social standing among colleagues. Similarly, one interviewee found it appealing that she would be the only one to possess formal qualification in teaching adults at her workplace. However, the employer's request could be perceived as somewhat contradictory to the employee's personal goals:

If it had not been an official request from my workplace [to enrol in the course], I do not think I would have gone this way. (Birgitte, D)

The need to obtain formal qualifications was also related to the need to improve one's own skills to better cope with the challenges posed by teaching adults in everyday professional practices. For one interviewee, teaching adults was something she first learned by doing. Then, she realised that transmitting knowledge was rather different from telling people about something she knew; hence, acquiring some kind of pedagogical knowledge become necessary for her. In fact, teaching adults 'was not the way forward' (Helene, D) unless she became qualified through further studies. Similarly, in another case, a theoretical foundation was perceived as a necessity. 
Getting some theory was super-exciting. Fundamentally, genuinely exciting, and it confirmed for me that a lot of the things we do [at work] are really good - we do a lot of things that, in theory, are also the way to get adults to learn. But, there are also a lot of things where I think we should do things differently. We need to realise this and get the teachers with us. (Lone, D)

One additional factor that motivated interviewees to enrol in existing education and training opportunities at the employer's request was a desire to share new insights about the theoretical foundation of their work and its related practical implications. To study with a colleague was a strategic way to reinforce one's own affiliation to the professional community of teachers.

For others, the choice was related to what is described above as a 'plan B'. Some interviewees were seeking an alternative opportunity to pursue a professional career because of exogenous factors that hampered progression in their prior job; hence, the primary motive to enrol in further studies was to make use of both the vocational knowledge they possessed and the experience they had gained on the job:

[The reason I enrolled was] that I could see the point in using my vocational background. It was a different way to use it - thus a way to preserve it. (Hanne, D)

Influences from a 'significant other' were not only related to entering adult education in general but also to the selection of specific courses, as personal contacts seemed to aid in student recruitment. The particular choice to enter adult education was also described as a sort of coincidence; one interviewee mentioned how she simply 'got to know about this course' (Elisabeth, S) randomly. For some interviewees, a shorter course in adult education/learning provided inspiration to enter a longer programme.

\section{Changes of focus in becoming an adult educator}

A trend in our sample of people becoming adult educators can be identified: affiliation with professional groups is generally a significant element, although not necessarily the most important one. Multiple affiliations with actual or imaginary communities also play an important role in becoming an adult teacher. Current participation in specialised studies supports these processes because it creates new opportunities to move from a peripheral to a more central position in the affiliated communities.

We have identified three categories in interviewees' descriptions of themselves in a professional context. This variation seems to relate to the interviewees' own experience of teaching. First, the educational context and the learners were more prominent in the experienced interviewees' descriptions of themselves in a professional teacher context. Those without experience were more concerned about the teaching subject. 
It is very obvious that I am a scientist. Educational stuff is not my first choice. I am bad at the airy-fairy things, just talk about everything and nothing, keeping on talking. As a scientist, this is the way it is. Full stop! Nothing to discuss. (Emma, S)

My main point, so to speak, in my job is learning, and then what I teach is somewhat of secondary importance. (Kristina, S)

In addition, those with more teaching experience tended to concentrate more on becoming a teacher and how to teach. However, those with less teaching experience focused more on their personal development and on the subject. A number of interviewees referred to their approach to teaching: either they worked in a team and cooperated with colleagues, or they perceived teaching as a solipsistic activity with a personal focus that limited the potential for collegial work. In short, the relevance of collegial work in teaching was an important element that influenced the way our interviewees perceived themselves in the professional context. It thus strengthened their processes of becoming adult educators. This element can be captured in the following words by Dorthe, a freelance teacher who constantly changes her working context:

I see myself as being in a place where I am going, and I actually do not know where I am going. But, I hope that I am going somewhere where I have some colleagues that I can work well with. (Dorthe, D)

Furthermore, the interviewees' reflections on teaching are oriented either toward teaching methods or toward the relationship between teacher and learner. One challenge faced in the educational contexts was creating strong connections between the theoretical foundation of their profession and its everyday practices, all while being engaged in teaching-learning processes. Our interviewees recognised the difficulty of finding a balance between allowing the learner to express him or herself and challenging him or her to accomplish significant progress (Hanne, D).

Then, it is a big group of pupils that you should motivate and be able to give work tasks to. I will adapt to different conditions and needs. It is more difficult but also a fun challenge to see how you can make it! (Pernilla, S)

Thus, the interviewees' thoughts about and visions of the educator's professional context are related to their own experiences of teaching. Uncertified teachers focused more on the educational context, the participants and their own development as professionals. The experienced interviewees were more concerned about communicating with and relating to learners, whereas interviewees without prior teaching experience were more concerned about their knowledge and understanding of the subject and how their participants would perceive them. 


\section{Conclusions}

Individuals who become adult educators do not follow a straight route but rather take a winding road between education and work in various areas until turning points in life, and maybe significant others, prompt the individuals to enrol in adult educator studies. A desire to obtain a new career or to develop the existing one prompts them to enter the trajectory for becoming an adult teacher. Our study shows that many prospective adult educators already have experience with an adult learning context. The motives for the choice of studies are internal as well as external. For example, employers may require formal teacher qualifications for those already working as teachers, or the individuals may wish to develop their teacher knowledge and strengthen their teacher identity. Prospective adult educators' descriptions of themselves in a professional teacher context are related to their experiences with teaching. Those with more teaching experience focus more on the educational context and relationships with students instead of teaching methods and the teaching subject.

Although our results show different individual learning trajectories, we have identified two main types: 1) learning initiated by participation and guidance in the everyday practices of adult education, or 2) learning initiated by participating in and being guided by the formal system of 'opportunity structures' for adult educators-to-be. The learning trajectory follows one of two routes: 1 ) working as an uncertified educator and later studying adult education or 2) direct enrolment in a study programme. These different learning trajectories indicate different professionalisation processes as well as different learning conditions. We discuss these differences further in the following section.

\section{Discussion}

Finally, we examine the results concerning opportunity structures, along with the learning and professional development of adult educators, in relation to our theoretical starting points.

\section{Learning in different communities and curricula}

Life trajectories are developed from and within an individual and socio-cultural context, whereby family and work experiences influence the choice to study and become an educator. The life trajectory is thus intertwined with the learning trajectory, which we see as a lifelong one. These results respond to the identified need for more knowledge of the life histories of adult educators (Buiskool et al. 2009; Research-voor-Beleid/PLATO 2008) and focus on new/uncertified adult educators, which is a new perspective in contrast to studies of experienced adult educators' life histories (Maier-Gutheil and Hof 2011).

Despite individual variations, two types of learning trajectories that indicate different professionalisation processes as well as different learning conditions are identified. In the first case, the learning trajectory stemming from participation in the everyday practices of adult education, the individual enters an educational community of practice in the position of teacher/educator. Here, the individual can be considered a prospective adult educator on the periphery of the educational 
community of practice, learning the teaching profession as part of the daily work and in communication with more experienced adult educators (Lave and Wenger 1991). Through the apprenticeship, or a system for supporting learning activities, one enters the local practice of adult education, and guidance is provided by more experienced adult educators (Rogoff 1995). Through this daily commitment and collaboration (work/study), the prospective adult educator becomes more involved in the community of practice, and his or her professional identity is gradually shaped. The learning curriculum is enacted through the daily context of teaching. Thus, adult education is a community of practice in which not only participants but also educators are learners. In the second case, participating in the formal system of 'opportunity structures' for prospective adult educators, the individual starts in the position of a student. The learning context is normally higher education; therefore, a teaching curriculum more or less separated from the everyday practice of adult education presents essential differences in learning conditions.

In the first case, the learning trajectory starts in the professional community of practice where one is immediately acting as an educator. In the second case, the community of practice seeks to foster professional development through a teaching curriculum for later entrance into the professional community, and the only occasions for learning by acting are the periods of practicum integrated into the curriculum. These different conditions for developing a professional identity significantly impact interviewees' understandings of the profession and the implications of teaching adults.

Different types of learning processes are shaped by guidance from academic teachers in comparison to direction from professional adult educators engaged in the daily teaching of adults. An interdependent relationship connects individual learning processes and interpersonal processes of learning (Rogoff 1995). Being an adult educator in a working environment influences the way learning is constructed as a local, applied practice of adult education. Meanwhile, learning shaped in a formal, higher education context is influenced by theories of learning and other elements of a teaching curriculum. Thus, the 'profession' of an adult educator is not a uniform one. The existence of the two different learning trajectories identified here means individuals have different access to and use of experiential and theoretical knowledge. Learning in the everyday work of adult education may mean that teaching focuses less on common socio-cultural knowledge and theories of pedagogy than on local contexts and decisions about how to act in specific contexts (Köpsén 2008). Equally, learning through a teaching curriculum is influenced and shaped by university teachers' pedagogical choices, especially the theoretical attitude toward adult learning and the translation of those theories into practical action in an adult education context.

However, in many cases, the learning and the teaching curricula are combined or overlapping. The sample consists of people participating in courses for prospective/acting adult educators, which means that all of them take part in a teaching curriculum. However, many of them have prior and/or parallel experiences from work as adult educators, a 'learning curriculum', which forms a significant part of their learning trajectories.

Furthermore, an individual's personal situation and family history shape and impact the intertwining trajectories of life and learning. In these trajectories, important turning points, individual incentives and external demands have been identified. Individuals have personal motives 
for developing teacher competencies and for teaching adults in particular. The need for formal qualifications emerges from external demands and influences the choice to enter a teaching programme or course for adult learning. Although there is no absolute connection between actual competence and formal qualification (Ellström 1992), external demands for formal qualifications drive individuals to participate in teacher education or a course related to adult learning.

\section{Understanding the profession of an adult educator}

The adult educator is not a profession in the classical meaning (Jütte et al. 2011). However, by applying a more process-oriented perspective, we see a variation in the results concerning professional development, both in the degree to which an adult educator sees him/herself as a member of a profession and in the interviewees' definitions of themselves as part of such a profession and professional context. These definitions are associated with individual teaching experiences as well as to specific contexts of adult education. By engaging in activities through the community of practice, one gains an understanding of the required tasks, professional values and traditions as well as the ways to act, talk and relate to others, i.e., one develops a professional identity (Lave and Wenger 1991; Milana, Andersson, Farinelli et al. 2010; Milana, Andersson, Gross et al. 2010). This process has also been identified in our field study. The uncertified, active educators who participated in this study were more aware of the educational context, the activities of teaching and the relationships with participants. Thus, they are generally competent; they have already entered the trajectory of developing a professional identity as an adult educator and are more fully participating in the community of practice.

A newcomer who is not part of a socio-cultural context may face problems in imagining the actual work tasks. In this situation, the individual naturally pays more attention to his or her lack of self-confidence than to the work task per se and the students. After becoming familiar with the context and the work, one is no longer in a situation of peripheral participation; a more experienced educator has also developed an understanding of the profession. Focus extends beyond the subject or vocational content being taught to the skills of teaching, i.e., its methods and the relationships between teacher and students. More experience, it seems, also means that relationships become more central in the process of becoming a professional teacher.

\section{Vague opportunity structure for becoming an adult educator}

The trajectory for becoming an adult educator is not a 'straight' one. Other studies have identified the 'winding road' in professional trajectories from higher education to working life (Nyström et al. 2008); we have identified such indirect paths to obtaining teaching qualifications and working as an adult educator, which confirms but also gives more nuance to the 'fragmented' picture given in prior studies (Buiskool et al. 2009; Przybylska 2008; Research-voor-Beleid/PLATO 2008). Some prospective adult educators have come to a turning point and changed their paths from something completely different. Others have slipped onto the track, starting their teaching careers as uncertified educators. Relating trajectories and identities to opportunity structures, we concluded that all three of these factors (trajectories, identities and opportunity structures) are intertwined. Students who have more clearly expressed their desire to practise adult education seem to have more experience with adult 
education as students and/or uncertified educators.

Those with prior experience have developed actual competence in the practice of adult education. Their trajectories could be compared those of child minders whose experience and competence leads them to enter to a pre-school teaching programme. Andersson and Hellberg (2009) show how these child minders' experiences from the community of the pre-school help them develop a more central or full participation in the community of practice for teacher education at the university. Students in courses for adult educators similarly describe a more developed and competent participation if they have prior experiences in adult education.

The type of trajectory that is described as pursuing a (new) career often means changing professional communities from a prior profession/vocation to the practice of teaching, or from teaching without a qualification to becoming a professional educator. The individual and interpersonal levels are important for this choice, but external formal demands may also stem from the 'system' in which the person is situated, which has a 'need' for qualified educators. The 'plan B' trajectory is clearly related to individual and interpersonal levels in regard to trigger events such as illness. However, the system level has an influence here, as well, when structural circumstances such as unemployment act as trigger events.

The external demands to become a certified adult educator emerging from the system level are another aspect of the professionalisation process. Requiring formal qualifications is in accordance with the idea of a profession and is therefore part of a professionalisation process, which serves not only the system/employers but also the adult educators who wish to become a professional group.

Furthermore, the communities of practice from which the interviewees come influence their development of a professional identity as adult educators. For example, a strong, subject-based identity (e.g., biology) or a vocational/professional identity (e.g., nurse) is important in understanding the professional identity of an adult educator, which is related both to a subject/vocation and to the practice of adult education (Bron and Jarvis 2008). This could be understood in terms of a changing (from peripheral to central/full) participation in the adult education community of practice.

\section{Movement between theories and practical experiences central to developing the expertise of professional adult educators}

Finally, formal qualification paths are not the primary basis for becoming a legitimate adult educator in Denmark and Sweden, two countries with long traditions of adult education. This is because there are few targeted qualifications for adult educators. Rather, the individual learning trajectories indicate that adult educators develop actual competences that are crucial for their profession. Nevertheless, formal competence based on formal training could be important as part of the learning trajectory (Bron and Jarvis 2008). In particular, formal training could introduce explicit theoretical knowledge, something that is essential for adult educators to be perceived as a professional group.

Theoretical knowledge is crucial to increase the breadth and depths of understanding for practical experiences. However, formal education alone is not sufficient; learning in the practice of 
adult education is important to widen the focus of instruction to include the educational context and the adult learners. Thus, the movement between theories and practical experiences-between education/training for adult educators and the practice of adult education-is a central factor in developing the expertise of professional adult educators prepared to meet the current and future demands of adult education.

\section{References}

Abbot, A. 1988. The systems of professions. Chicago: The University of Chicago Press.

Andersson, E. 2007a. Country report: Denmark. (Unpublished report from the study of Researchvoor-Beleid/PLATO, 2008.)

Andersson, E. 2007b. Country report: Sweden. (Unpublished report from the study of Research-voorBeleid/PLATO, 2008.)

Andersson, P., and K. Hellberg. 2009. Trajectories in teacher education: Recognising prior learning in practice. Asia-Pacific Journal of Teacher Education 37, no. 3: 271-82.

Bertaux, D., and P. Thompson, eds. 1997. Pathways to social class. Oxford: Clarendon Press.

Bron, A., and P. Jarvis. 2008. Identities of adult educators: Changes in professionality. In Nuissl and Lattke 2008, 33-44.

Buiskool, B. J., J. Lakerveld, and S. Broek. 2009. Educators at work in two sectors of adult and vocational education. European Journal of Education 44, no. 2: 145-62.

Colnerud, G., and K. Granström. 2002. Respekt för läraryrket [Respect for the teacher profession]. Stockholm: HLS Förlag.

Cunningham, B., ed. 2008. Exploring professionalism. London: Bedford Way Papers.

EC. 2006. Communication from the commission - adult learning: It is never too late to learn. Brussels: Commission of the European Communities.

EC. 2007a. Action plan on adult learning: It is always a good time to learn. Brussels: Commission of the European Communities.

EC. 2007b. Communication from the commission to the council and the European parliament: Improving the quality of teacher education. Brussels: Commission of the European Communities.

Ellström, P-E. 1992. Kompetens, utbildning och lärande i arbetslivet [Competence, education and learning in the workplace life]. Stockholm: Publica/Norstedts.

European Journal of Education. 2009. 44, No. 2: 143-310. Special issue: The training of adult education professionals in Europe.

Evans, L. 2008. Professionalism, professionality and the development of education professionals. British Journal of Educational Studies 56, no. 1: 20-38. 
Fischer-Rosenthal, W. 2000. Biographical work and biographical structuring in present-day societies. In The turn to biographical methods in social science, ed. P. Chamberlayne, J. Bornat, and T. Wengraf, 109-25. London/New York: Routledge.

Horsdal, M. 2002. Grundtvig Socrates II: Active citizenship and the non-formal education. Copenhagen: Active Citizenship and Non-formal Education.

Jütte, W., K. Nicoll, and H.S. Olesen. 2011. Editorial: Professionalisation - the struggle within. European Journal for Research on the Education and Learning of Adults 2, no. 1: 7-20.

Köpsén, S. 2008. From revolution to retreat: Everyday learning in a trade union, Linköping Studies in Behavioural Science no. 124. Linköping and Stockholm: Linköpings universitet and Atlas förlag.

Lave, J., and E. Wenger. 1991. Situated learning: Legitimate peripheral participation. Cambridge, UK: Cambridge University Press.

Maier-Gutheil, C., and C. Hof. 2011. The development of the professionalism of adult educators: A biographical and learning perspective. European Journal for Research on the Education and Learning of Adults 2, no. 1: 75-88.

Merriam, S. B., and R. G. Brockett. 2007. The profession and practice of adult education. San Francisco: John Wiley \& Sons.

Milana, M., ed., P. Andersson, F. Farinelli, M. Gross, L. Jõgi, S. Köpsén, and A. Larson. 2010. BAEA: Becoming adult educators in the European area. Synthesis research report. Copenhagen: Danish School of Education, Aarhus University.

Milana, M., ed., P. Andersson, M. Gross, L. Jõgi, S. Köpsén, and A. Larson. 2010. BABAR: Becoming adult educators in the Baltic-Sea region. Synthesis report. Linköping: Linköping University Electronic Press.

Nuissl, E., and R. Egetenmeyer, eds. 2010. Teachers and trainers in adult education: European and Asian perspectives. Bielefeld: W. Bertelsmann Verlag.

Nuissl, E. and S. Lattke, eds. 2008. Qualifying adult learning professionals in Europe. Bielefeld: W. Bertelsmann Verlag.

Nyström, S., M. Abrandt Dahlgren, and L. O. Dahlgren. 2008. A winding road - professional trajectories from higher education to working life. Studies in Continuing Education 30, no. 3 : 215-29.

Przybylska, E. 2008. Pathways to becoming an adult education professional in Europe. In Nuissl and Lattke 2008, 87-100.

Research-voor-Beleid/PLATO. 2008. ALPINE - Adult learning professionals in Europe: A study of the current situation, trends and issues. Final report. Zoetermeer: Authors. 
Rogoff, B. 1995. Observing socio cultural activity on three planes: Participatory appropriation, guided participant, and apprenticeship. In Socio cultural studies of mind, ed. J. Wertsch, P. Del Rio, and A. Alvarez, 139-64. Cambridge: Cambridge University Press.

Santoro, N. 2003. Caught up in the teaching-training divide: confusing professional identities. Studies in Continuing Education 25, no. 2: 211-24.

Vähäsantanen, K., and A. Eteläpelto. 2009. Vocational teachers in the face of a major educational reform: Individual ways of negotiating professional identities. Journal of Education and Work 22, no. 1: 15-33.

Wenger, E. 1998. Communities of practice: Learning, meaning, and identity. Cambridge, UK: Cambridge University Press. 